\title{
ANALISIS PERSEPSI DAN ATRAKSI WISATA ALTERNATIF UNTUK MENDUKUNG PENGEMBANGAN KAWASAN AIR TERJUN TIU TEJA, LOMBOK UTARA
}

\author{
The Analysis Of Perception And Alternative Tourist Attractions To SupportThe \\ Development Of Tiu Teja Waterfall Area, North Lombok
}

Kornelia Webliana, Maiser Syaputra, Dwi Sukma Rini

Program Studi Kehutanan, Universitas Mataram JI Majapahit No 62, Mataram, NTB

Email :yeniwebliana@gmail.com

\begin{abstract}
Tiu Teja waterfall is one of nature tourism which is currently well known by the community and get important attention from the Government of North Lombok Regency. The development of Tiu Teja Waterfall tourism is expected to support the economy of the surrounding villages by engaging in tourism activities. Implementation of research aims to analyze the market and tourist products as well as analyze the supporting attractions or alternative tourist attractions that become one unity of Destination with Tiu Teja Waterfall area. The results showed that the visit in the period of April to October 2017 is dominated by domestic tourists with the pattern of adventure tourism journey. Analysis of the components of the tourist market shows several factors that lead to dissatisfaction in the tour of the difficulty of location attainment, inadequate supporting facilities, lack of accommodation facilities, lack of trading facilities and other factors. Tourism Product Analysis describes the types of supporting attractions around the Waterfall area in the form of landscape, agrltourism, cultural and culinary tourism. Types Tourist attractions Tiu Teja supporters are then categorized into natural attractions, cultural attractions and manmadeattractions. This supporting attraction can be used as an alternative tour around the Forest Area of Santong Village. The result of this study is expected to be considered in planning development Waterfall tour as one of North Lombok tourist destination.
\end{abstract}

Keywords: Tourist attraction, Tourist market, Tourist Product, Tiu Teja

\begin{abstract}
Abstrak
Air terjun Tiu Teja merupakan salah satu wisata alam yang saat ini cukup dikenal oleh masyarakat dan mendapatkan perhatian penting dari Pemerintah Kabupaten Lombok Utara. Pengembangan wisata air terjun Tiu Teja diharapkan dapat mendukung perekonomian masyarakat desa sekitar kawasan dengan cara terlibat dalam kegiatan kepariwisataan. Pelaksanaan penelitian bertujuan untuk menganalisis pasar dan produk wisatawan serta menganalisis atraksi pendukung atau atraksi wisata alternatif yang menjadi satu kesatuan destinasi dengan kawasan air terjun Tiu Teja. Hasil penelitian menunjukkan kunjungan dalam periode April sampai Oktober 2017 didominasi oleh wisatawan domestik yang menyukai pola perjalanan adventure tourism. Analisis komponen pasar wisatawan menjelaskan faktor yang mengakibatkan ketidakpuasan dalam berwisata yaitu kesulitan pencapaian lokasi, sarana penunjang yang kurang memadai, kurangnya sarana akomodasi, kurangnya fasilitas perdagangan dan faktorfaktor lainnya. Sedangkan hasil analisis produk wisata menyimpulkan masyarakat sangat mendukung pengembangan wisata air terjun Tiu Teja dengan memaksimalkan atraksi lain di sekitar kawasan air terjun yaitu berupa landscape, Agrotourism, wisata budaya dan
\end{abstract}


kuliner. Atraksi pendukung ini dapat dijadikan sebagai wisata alternatif di sekitar Kawasan Hutan Desa Santong. Hasil penelitian ini diharapkan dapat menjadi pertimbangan dalam perencanaan pembagunan wisata air Terjun sebagai salah satu destinasi wisata Lombok Utara.

Kata Kunci : Atraksi wisata, Pasar wisata, Produk Wisata, Tiu Teja

\section{Pendahuluan}

Wisata alam dapat diartikan sebagai obyek dan kegiatan yang berkaitan dengan rekreasi dan pariwisata yang memanfaatkan potensi sumber daya alam dan ekosistemnya, baik dalam bentuk asli atau alami maupun perpaduan dengan buatan manusia. Saat ini tempat-tempat rekreasi di alam terbuka yang sifatnya masih alami dan dapat memberikan kenyamanan semakin banyak dikunjungi wisatawan. Meningkatnya kegiatan wisata alam ada kaitannya dengan perubahan pola hidup masyarakat, meningkatnya taraf kehidupan, adanya pertambahan waktu luang dan semakin meningkatnya fasilitas sarana dan prasarana suatu kawasan sehingga dapat dijangkau oleh wisatawan dari berbagai daerah.

Salah satu kawasan hutan yang saat ini sedang mengembangkan potensi wisata alamnya adalah kawasan air terjun Tiu Teja yang berada di desa Santong Kabupaten Lombok utara. air terjun Tiu Teja berada pada kawasan hutan produksi dibawah pengelolaan Koperasi Maju Bersama melalui SK Pencadangan Areal Kerja oleh Menteri Kehutanan Nomor : 447/Menhut-II/2009 seluas 758 dan Izin Usaha Pemanfaatan Hutan Kemasyarakatan oleh Bupati Lombok Utara No : 188.45/366/HUTBUN/2010. Unit Usaha Pemanfaatan HKm berperan untuk mengelola hasil hutan baik buka kayu dan jasa lingkungan yang ada di dalam wilayah kerja HKm Santong seluas 758 ha (Profil Kelompok, 2017).

Air terjun Tiu Teja merupakan salah satu atraksi wisata yang saat ini cukup dikenal oleh masyarakat dan mendapatkan perhatian penting dari pemerintah Kabupaten Lombok Utara. Kondisi air Terjun Tiu Teja yang berada di dalam kawasan hutan tentunya sangat menjanjikan untuk pengembangan wisata minat khusus dan wisata ekologis, hal ini tentunya memberikan peluang bagi masyarakat Desa Santong yang memiliki akses pemanfaatan untuk dapat meningkatkan perekonomian dengan cara terlibat dalam kegiatan kepariwisataan.

Melihat pentingnya pengembangan wisata Air Terjun Tiu Teja untuk mendukung perekonomian masyarakat sekitar, maka perlu dilakukan penilaian persepsional untuk mendukung pembangunan wisata air terjun Tiu Teja yang dilakukan pada dua kelompok penting, yaitu kelompok wisatawan (pasar wisata) dan kelompok pengelola koperasi (produk wisata). selain itu perlu dilakukan kajian terkait informasi wisata pendukung atau wisata alternatif yang menjadi satu kesatuan destinasi dengan kawasan air terjun Tiu Teja. Oleh karena itu pelaksanaan penelitian ini penelitian bertujuan (1) untuk menganalisis pasar wisata dan produk wisata, (2) menganalisis atraksi pendukung wisata air Terjun Tiu Teja. Hasil penelitian diharpakan dapat menjadi pertimbangan dalam perencanaan pembangunan wisata air terjun sebagai salah satu destinasi wisata Lombok Utara.

\section{Metode}

\section{Lokasi dan Waktu Penelitian}

Penelitian ini dilaksanakan pada bulan Oktober sampai bulan Desember 2017 dan berlokasi di Desa Santong Kabupaten Lombok Utara. Metode Pengambilan data dilakukan dengan berbagai tahapan yaitu sebagai berikut : 


\section{a. Studi literatur}

Studi literatur merupakan kegiatan awal yang dilakukan untuk mengumpulkan data berupa data sekunder seperti peta, laporan kegiatan, laporan kunjungan, profil Desa, laporan biofisik, hasil penelitian dan kajian terkait wisata alam di Desa Santong

\section{b. Observasi}

Observasi dalam kegiatan ini dilakukan dengan teknik pengamatan langsung di lapangan selama 1 bulan, peneliti terlibat dalam beberapa kegiatan-kegiatan yang dilakukan oleh masyarakat dan pegunjung ketika beraktivitas di wilayah air terjun Tiu Teja.

\section{c. Wawancara Mendalam}

Menurut Mulyana (2006) wawancara mendalam atau wawancara tidak terstruktur bersifat lebih luwes, susunan pertanyaannya dan susunan kata-kata dalam setiap pertanyaan dapat dirubah pada saat wawancara, disesuaikan dengan kebutuhan dan kondisi pada saat wawancara. Wawancara mendalam dilakukan dengan menggunakan panduan pertanyaan kepada 30 orang wisatawan. Pengambilan data terkait sumber informasi dan frekuensi partisipasi wisatawan menggunakan teknik pengambilan data accident sampling.

\section{d. Focus Group Discussion (FGD)}

Focus Group Discussion (FGD) dilakukan dengan tujuan menemukan makna sebuah tema menurut pemahaman sebuah kelompok (Bungin, 2003). Pemahaman yang dimaksudkan dalam penelitian ini berhubungan dengan penetapan jenis atraksi pendukung serta perencanaan pembangunan sarana dan prasarana di sekitar kawasan Air Terjun Tiu Teja. Para peserta FGD merupakan orang-orang yang memiliki pengetahuan khusus atau warga masyarakat yang paling mengetahui tentang topik kajian (AC Ichsan et al, 2016).

\section{Analisis}

penelitian ini menggunakan analisis deskriptif sebagai kerangka pendekatan kajiannya.Secara konseptual analisis deskriptif merupakan salah satu instrumen ilmiah yang bertujuan untuk mengumpulkan informasi yang ada pada saat sekarang, menganalisisnya dan menginterpretasikan fakta atau informasi yang ditemukan (Narbuko, 2003). Hasil akhir dari penilaian ini disajikan dalam bentuk persentase, indeks, dan naratif.

\section{Hasil dan Pembahasan}

Secara umum komponen yang terkait dalam kepariwisataan dibagi menjadi dua yaitu produk dan pasar wisata. Komponen yang termasuk dalam produk wisata adalah jenis atraksi, perilaku atraksi alam, pemberdayaan masyarakat, kondisi ekonomi masyarakat, sumberdaya manusia dan lingkungan.Komponen yang termasuk dalam pasar wisata yaitu lama tinggal, aktivitas, persepsi, preferensi, kepuasan dan tingkat pengalaman.

\section{Analisis Pasar wisatawan}

a) Karakteristik sosio-demografi dan grografis wisatawan

Analisis sosio-demografi dan geografis wisatawan diperoleh dari data sekunder koperasi Maju Bersama Santong. Berdasarkan informasi kunjungan objek wisata Tiuteja pada bulan April sampai dengan bulan Oktober 2017, diperoleh data 
kunjungan wisatawan yaitu 183 orang dengan tipe dan usia yang bervariasi. Data sosio-demografi dan geografis wisatawan dapat dijelaskan pada gambar berikut :
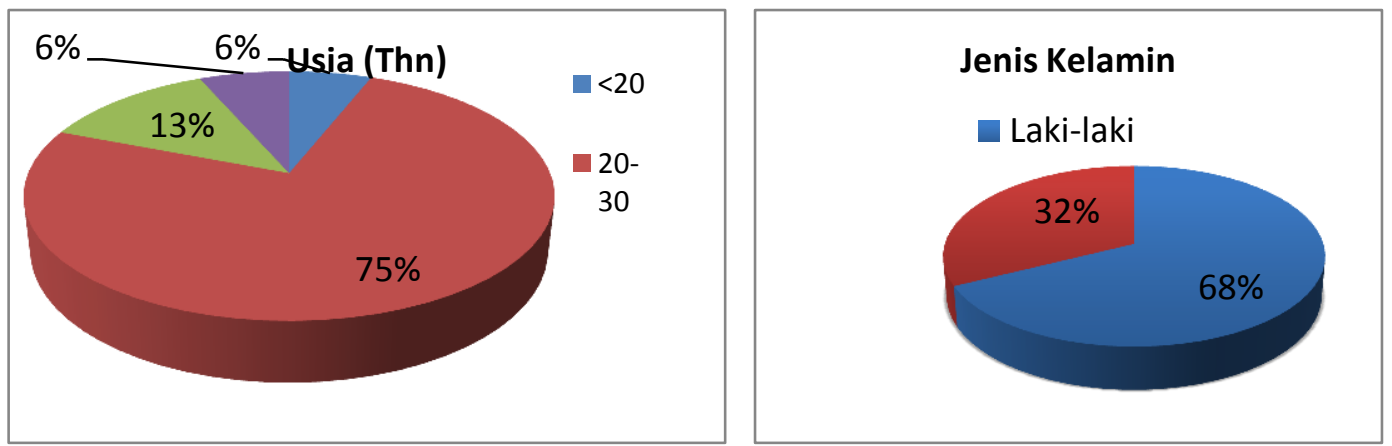

Gambar 1. Karakteristik sosio-demografi wisatawan

Figure 1. The Socio-degraphic Characteristics of Tourists

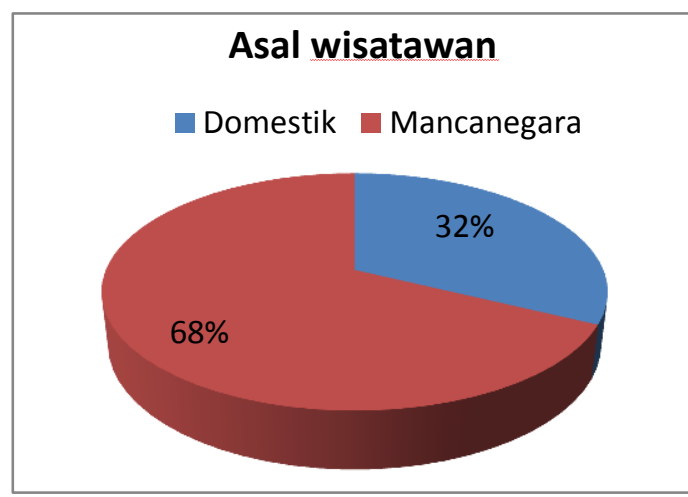

Gambar 2. Karakteristik geografis wisatawan

Figure 2. The Geographical Characteristics of Tourists

Keunikan atraksi wisata Tiu Teja menjadikan wilayah ini diminati oleh wisatawan mancanegara yang cenderung menyukai wisata yang berbentuk adventure tourism atau wisata petualangan. Hal ini terlihat dari jumlah kunjungan wisatawan yang didominasi oleh wistawan mancanegara dengan jumlah $68 \%$ dan wisatawan domestik sejumlah 32\%. Bentuk adventuring tourism ini berupa treking, dan hiking, penelusuran sungai dan enriching yang bertujuan untuk memperkaya pengalaman bagi wisatawan (Fandeli, 2001).

Wisatawan Tiu Teja didominasi oleh laki-laki dengan jumlah $68 \%$ dan wisatawan perempuan $32 \%$. Perbandingan persentasi kunjungan antara wisatawan laki-laki dan perempuan ini dapat disebabkan oleh kecenderungan laki-laki dalam aktivitasaktivitas yang menantang dan memacu adrenalin, sedangkan perempuan lebih cenderung menyukai wisata yang menyenangkan seperti penelitian alam dan budaya serta ekowisata yang diharapkan dapat menambah pengetahuan baru.

Wisatawan air terjun Tiu Teja terdiri dari berbagai golongan usia, dan usia yang mendominasi adalah 20-30 tahun yaitu sejumlah 75\% dan 30-40 tahun sejumlah $13 \%$. Hal penting yang harus diperhatikan adalah ada $6 \%$ wisatawan berada pada golongan usia $>40$ tahun. Wisatawan yang berada pada golongan usia ini tentunya memiliki pola dan motivasi perjalanan wisata yang berbeda, karena itu perlu disediakan fasilitas yang dapat mengakomodir wisatawan dengan golongan usia tersebut. 


\section{b) Sumber Informasi dan frekuensi partisipasi wisatawan}

Pengumpulan data terkait sumber informasi dan frekuensi partisipasi wisatawan menggunakan metode observasi langsung dengan teknik pengambilan data accidentsampling. Wawancara dilakukan kepada 30 orang pengunjung pada bulan Oktober tahun 2017 dengan jenis pertanyaan meliputi motivasi kunjungan, sumber informasi, lama kunjungan dan juga tingkat kepuasan pengunjung. Dari hasil wawancara diperoleh data sebagai berikut :
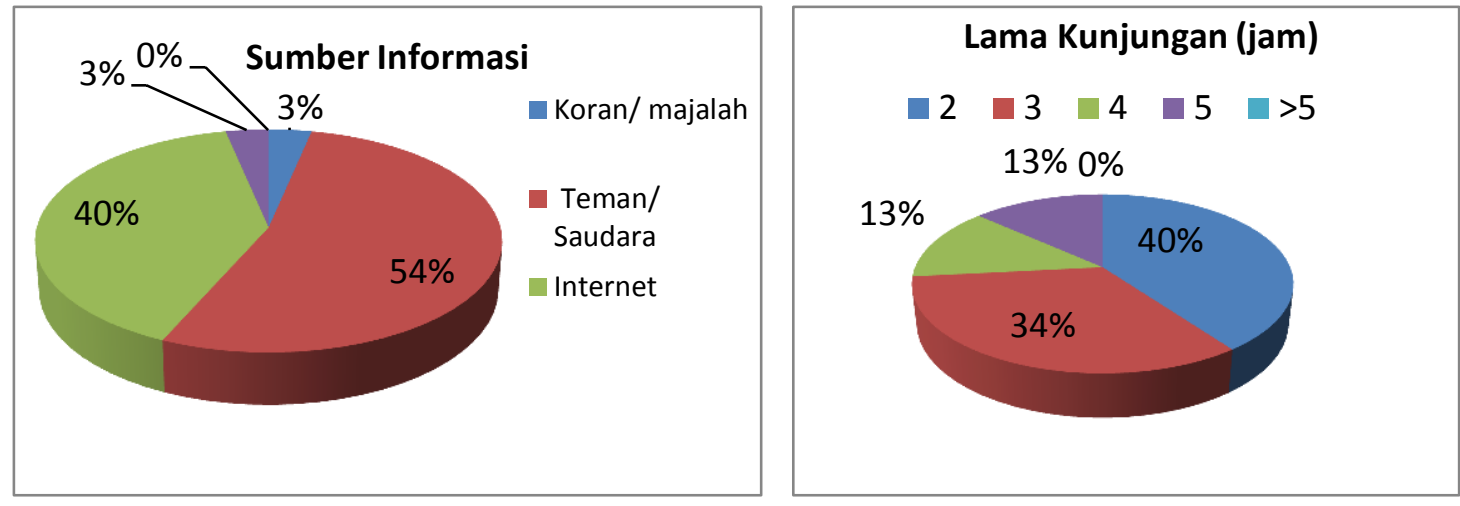

Gambar 3. Sumber Informasi dan frekuensi partisipasi wisatawan

Figure 3. The Information Sources and Frequency of Tourists Participation

Publikasi memiliki tiga tahapan yaitu penyebaran informasi, penanaman kepercayaan dan keyakinan lalu diikuti dengan penjualan. Publikasi intern adalah segala jerih payah untuk menjaga kondisi atraksi, jasa dan angkutan wisata agar selalu memuaskan bagi wisatawan dan kemudian diceritakan kepada orang lain. Pengaruh intern tidak dapat berjalan terus menerus, namun pengaruh baru dari cerita wisatawan yang berkunjung ke daerah yang sama akibat promosi dan publikasi media masa contohnya seperti internet akan kembali menarik wisatawan (Soekadijo 1996). Berdasarkan hasil wawancara dapat diketahui publikasi wisata Tiu Teja dilakukan secara Intern yaitu melalui teman/saudara dengan jumlah 54\%.

Publikasi melalui media internet juga dilakukan wisatawan untuk mempromosikan Tiu Teja, hal ini tergambar dari hasil wawancara dimana sejumlah $40 \%$ wisatawan mengetahui informasi terkait atraksi wisata dari media internet. Bentuk publikasi yang dilakukan ini bertujuan untuk memancing aksi pasar, menggerakkan calon konsumen agar mencari produk yang ditawarkan. Media internet mudah diakses oleh semua orang dan merupakan bentuk publikasi yang murah, namun tetap harus bertujuan untuk menjual produk pariwisata.

\section{c) Motivasi kunjungan wisatawan}

Salah satu kelompok motif wisata menurut Soekadijo (1996) adalah motif fisik atau fisiologis, yaitu motif yang berhubungan dengan kebutuhan badaniah, seperti olahraga, istirahat, rekreasi, kesehatan dan sebagainya. Wisatawan Tiu Teja dapat dikelompokan menjadi wisatawan yang memiliki motif untuk penelitian, rekreasi, pendidikan dan lain-lain. Gambaran terkait motivasi kunjungan wisatawan dapat dijelaskan sebagai berikut: 


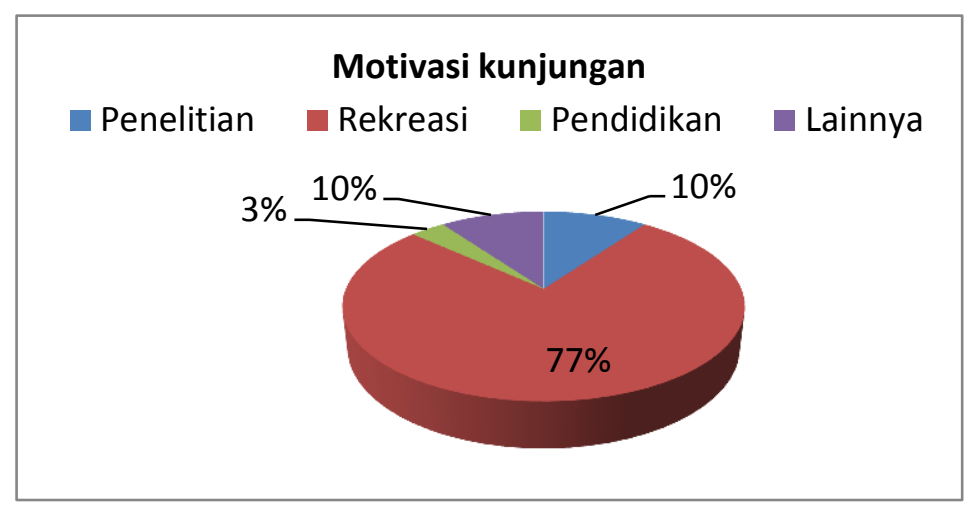

Gambar 4. Motivasi kunjungan wisatawan

Figure 4. The Tourists Visits Motivation

Tujuan kunjungan wisatawan terbesar adalah $77 \%$ untuk rekreasi dan sebanyak $23 \%$ memiliki motivasi lain seperti penelitian, pendidikan dan lainnya. Pada hakikatnya tujuan atau motivasi seseorang untuk berkunjung pada suatu tempat tidak terbatas dan tidak dapat dibatasi. Motivasi terbentuk karena adanya kebutuhan yang dimulai dari kebutuhan fisiologis, kebutuhan keamanan, kebutuhan sosial, kebutuhan prestise, dan kebutuhan aktualisasi diri.

\section{d) Kepuasan Pengunjung}

Kepuasan pengunjung merupakan faktor penting yang harus diperhatikan dalam komponen perencanaan wisata alam. Penilaian kepuasan dapat mempengaruhi keinginan wisatawan untuk berkunjung kembali dan mempromosikan atraksi wisata kepada orang lain. Kepuasan pengunjung pada atraksi wisata air terjun Tiu Teja dapat dilihat pada gambar di bawah ini:
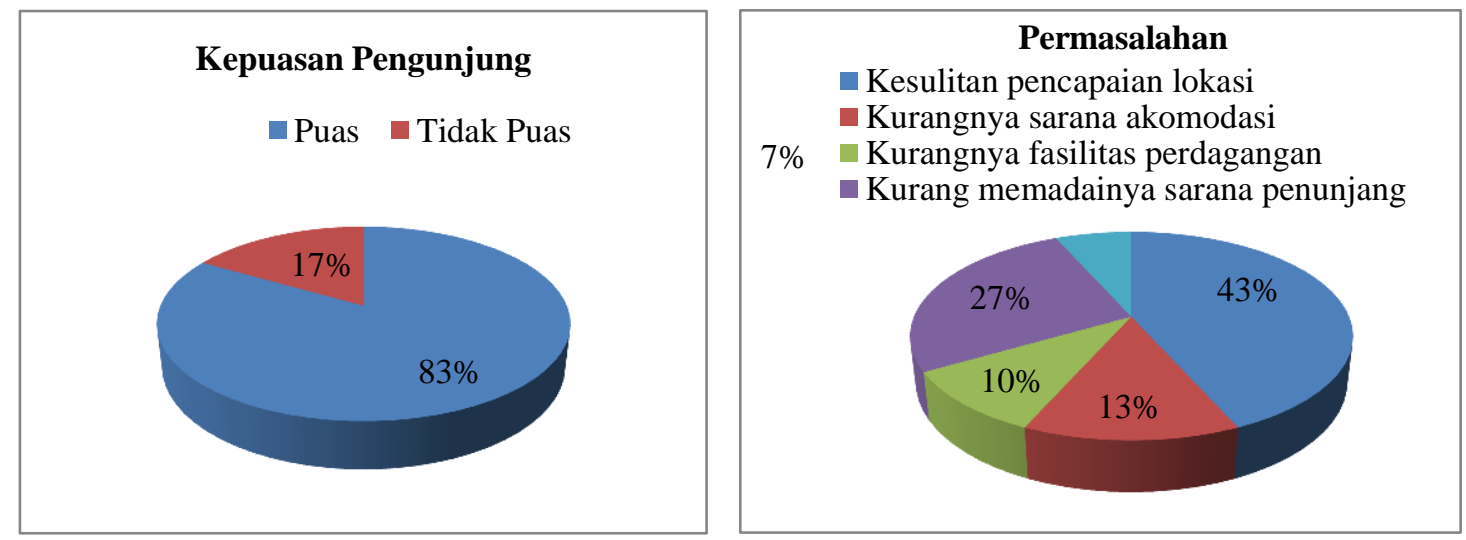

Gambar 5. Kepuasan pengunjung

Figure 5. The Visitor Satisfaction

Kepuasan wisatawan dalam melakukan perjalanan wisata antar satu orang dan orang lain berbeda-beda, berdasarkan hasil wawancara diperoleh sejumlah $83 \%$ wisatawan merasakan kepuasan dalam berwisata di kawasan air terjun Tiuteja. Alasan yang mendasari kepuasan ini adalah landscape di sekitar kawasan Tiuteja yang sejuk dan menarik, kondisi sungai yang jernih, dan pemandangan air terjun yang indah. Berdasarkan hasil wawancara juga diperoleh $17 \%$ wisatawan yang belum merasakan kepuasan di dalam berwisata, hal ini disebabkan karena beberapa faktor dominan seperti kesulitan pencapaian lokasi (43\%), sarana penunjang yang kurang memadai $(27 \%)$, kurangnya sarana akomodasi (13\%), kurangnya fasilitas perdagangan $(10 \%)$ dan faktor-faktor lain seperti keamanan dan keramahan dari masyarakat. 


\section{e) Persepsi wisatawan terkait sarana prasarana, pengelolaan wisata dan aksesibilitas}

Selain atraksi wisata, komponen penting dalam pengembangan suatu destinasi wisata adalah aspek amenitas dan aksesibilitas. Kedua aspek ini berkaitan erat dengan kenyamanan seseorang di dalam berwisata, dalam arti pemenuhan sarana dan prasarana serta jaminan keselamatan bagi wisatawan. Sarana wisata merupakan kelengkapan daerah tujuan wisata yang diperlukan untuk melayani kebutuhan wisatawan dalam menikmati perjalanan wisatanya. Sedangkan prasarana dapat dibagi mejadi prasarana akomodasi dan prasarana pendukung. Prasarana akomodasi di wilayah Tiu Teja direncanakan berbentuk homestay yang pengelolaannya dilakukan secara tradisional dengan melibatkan masyarakat Desa Santong. Prasarana pendukung berupa fasilitas beribadah, kuliner, tempat beristirahat dan fasilitas bermain yang direncanakan akan dimaksimalkan pada di pintu masuk kawasan air terjun. Berikut ini merupakan gambaran persepsi wisatawan terkait sarana prasarana, pengelolaan dan aksesibilitas di kawasan Tiu Teja.

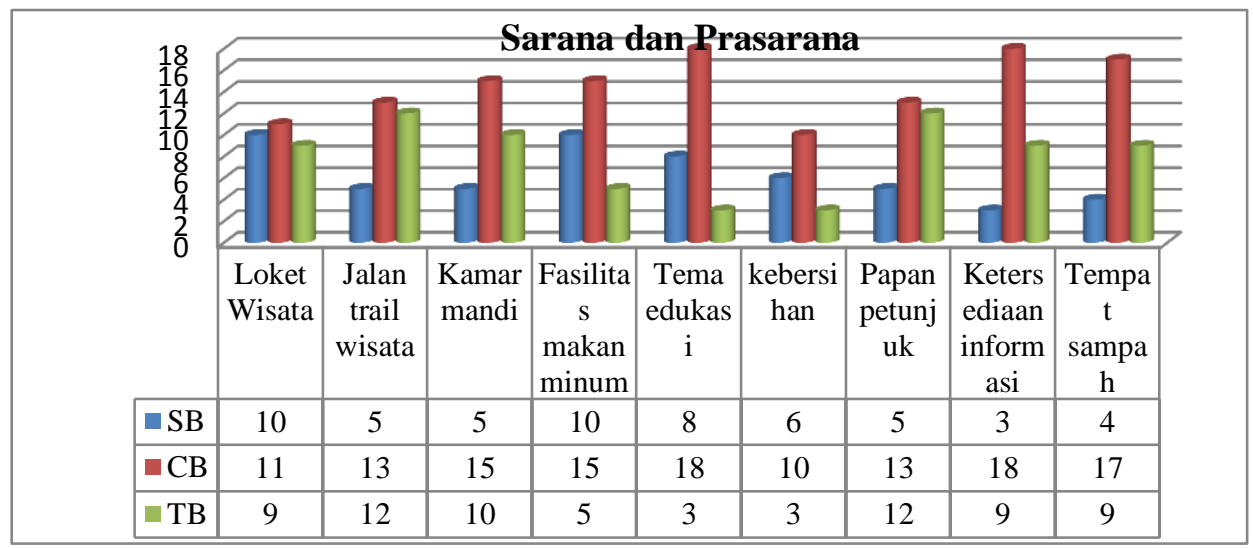

Gambar 6. sarana dan prasarana di sekitar kawasan Air terjun Figure 6. The Facilities and Infrastucture Around the Waterfall

\begin{tabular}{|c|c|c|c|c|c|c|}
\hline \multicolumn{7}{c|}{ Aksesibilitas } \\
\hline
\end{tabular}

Gambar 7. Aksesibilitas menuju ke kawasan wisata

Figure 7. The Accessibility to the Tourists Area

Kondisi sarana dan prasarana pada kawasan Tiu Teja masih sangat minim. Hal ini tentunya menjadi perhatian bagi pengelola, mengingat kawasan Tiu Teja saat ini sudah mulai dikenal olah masyarakat luas. Sarana dan prasarana tidak hanya terbatas pada fasilitas/bangunnan pda kawasan wisata, tetapi juga dapat diartikan sebagai sistem informasi kepariwisataan alam seperti informasi, ketersediaan peta, 
leaflet, booklet, dan informasi lain terkait lokasi wisata (Fandeli,2005) . Kurangnya pemenuhan terhadap aspek ini dapat menurunkan kenyamanan dan kepuasan wisatawan dalam berwisata. Informasi-informasi yang tersedia pada suatu objek daya tarik wisata dapat membantu wisatawan untuk mengenal objek wisata tersebut baik itu jenis atraksi yang tersedia, budaya dan sejarah kawasan.

\section{Analisis Produk wisata}

Salah satu komponen dalam produk wisata adalah persepsi dari pengelola wisata. wawancara dengan pengelola wisata bertujuan untuk menggali informasi terkait jenis atraksi pendukung di sekitar kawasan, permasalahan serta harapan dari pengelola. Informasi tersebut diperoleh dari dua puluh orang masyarakat yang dirangkum dalam Tabel 1 berikut :

Tabel 1. Persepsi Pengelola wisata

Table 1. The Perception of Tourists Manager

\begin{tabular}{|c|c|c|}
\hline No & Aspek kajian & Jawaban Pertanyaan \\
\hline 1 & $\begin{array}{l}\text { Atraksi pendukung di } \\
\text { kawasan Tiu Teja }\end{array}$ & $\begin{array}{l}\text { Terdapat jenis atraksi yang dapat menjadi } \\
\text { pendukung yaitu berupa atraksi air terjun seperti } \\
\text { Skeper, Sampurarung dan Batu Lawang. Selain itu } \\
\text { dapat dikembangkan Agrotourism, wisata budaya } \\
\text { dan wisata kuliner. }\end{array}$ \\
\hline 2 & Konflik yang terjadi & $\begin{array}{l}\text { Belum pernah ada konflik antara pengelola dengan } \\
\text { masyarakat. Masyarakat di luar pengelola koperasi } \\
\text { juga diberikan kesempatan untuk menjadi Naturalis } \\
\text { Guide dan penyedia transportasi. }\end{array}$ \\
\hline 3 & $\begin{array}{l}\text { Bentuk partisipasi } \\
\text { masyarakat }\end{array}$ & $\begin{array}{l}\text { Dalam kegiatan pengamanan, kebersihan dan } \\
\text { menjadi penyedia sarana trasnportasi lokal (Ojek). }\end{array}$ \\
\hline 4 & $\begin{array}{l}\text { Program yang dilakukan } \\
\text { pemerintah }\end{array}$ & $\begin{array}{l}\text { Dilakukan pelatihan sebagai naturalis guide serta } \\
\text { pelatihan untuk meningkatkan keterampilan } \\
\text { membuat anyaman bambu. Pelatihan ini difasilitasi } \\
\text { oleh pemerintah dan sejauh ini belum rutin dilakukan }\end{array}$ \\
\hline 5 & $\begin{array}{l}\text { Pendapat terkait Desain } \\
\text { pengembangan Tiu Teja }\end{array}$ & $\begin{array}{l}\text { Masyarakat } 100 \% \text { mendukung pengembangan Tiu } \\
\text { Teja sebgai atraksi wisata dan melihat hal ini sebagai } \\
\text { peluang untuk meningkatkan perekonomian } \\
\text { masyarakat. }\end{array}$ \\
\hline 6 & Kendala yang dirasakan & $\begin{array}{l}\text { Sarana dan prasaarna belum memadai, keterlibatan } \\
\text { pemerintah masih sangat minim, dan kegiatan } \\
\text { penataan belum terorganisir dengan baik }\end{array}$ \\
\hline 7 & Harapan & $\begin{array}{l}\text { Pemerintah/swasta memberikan pelatihan yang rutin } \\
\text { kepada masyarakat, membantu pemenuhan sarana } \\
\text { dan prasarana, pendampingan kepada pengelola } \\
\text { agar desain pembangunan wisata Tiu Teja dapat } \\
\text { segera terealisasi }\end{array}$ \\
\hline
\end{tabular}

\section{AtraksiPendukung}

Berdasarkan hasil analisis yang dilakukan dapat disimpulkan pengembangan atraksi di Desa santong dapat dikategorikan menjadi atraksi alam (nature), atraksi budaya (culture), dan atraksi buatan manusia (man made). Berikut ini merupakan gambaran jenis atraksi yang dapat dikembangkan guna mendukung kawasan Tiuteja sebagai kawasan wisata. 


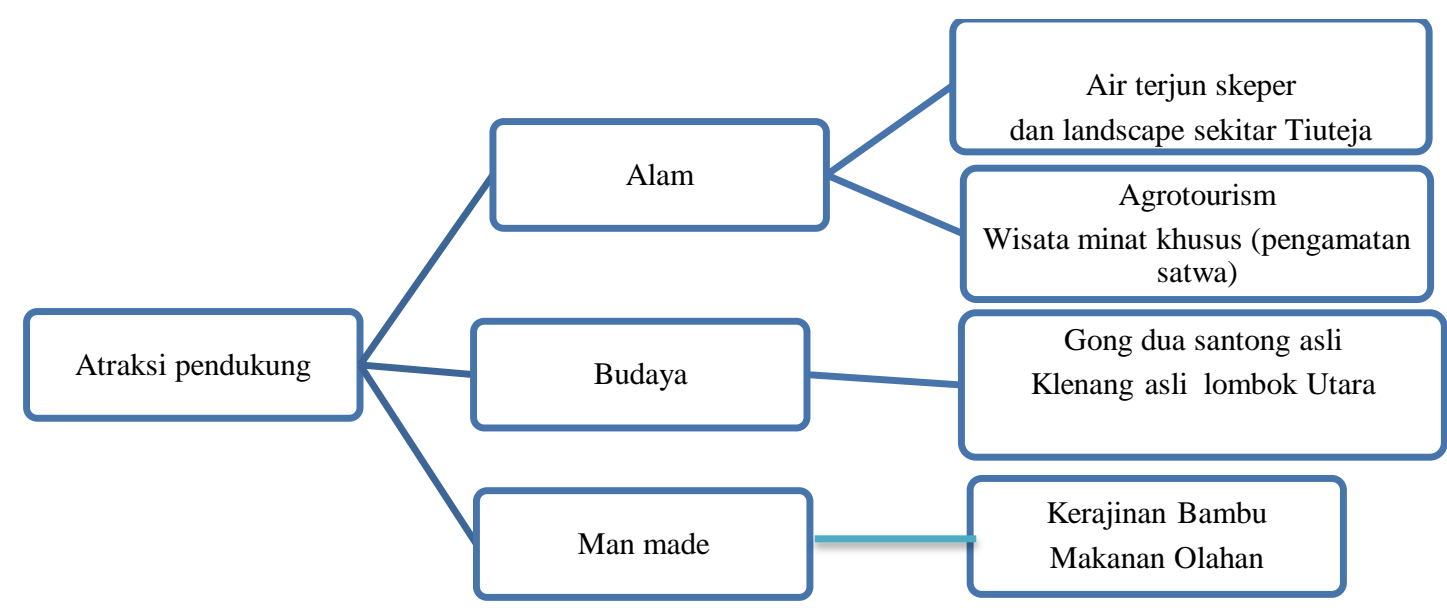

Gambar 1. Jenis Atraksi yang dapat dikembangkan

Figure 8. The Type of Attraction to be Developed

Air Terjun Tiu Teja merupakan atraksi utama yang saat ini mulai dikenal oleh masyarakat luas, namun dalam perkembangannya kawasan sekitar air terjun Tiu Teja juga dapat dikembangan sebagai alternatif wisata. Atraksi pendukung tersebut dapat dijelaskan sebagai berikut :

\section{a. Wisata Tirta}

Air terjun dan sungai Tiu Teja memiliki keindahan dan keunikan tersendiri yang menjadikannya sebagai atraksi utama desa Santong. Pada air terjun ini akan ditata beberapa spot yang akan digunakan sebagai areal untuk pemandian anak dan jenis wahana air lainnya. Namun Berdasarkan pertimbangan-pertimbangan dampak ekologis, akan dilakukan pembatasan jumlah wisatawan guna meminimalisasi dampak yang akan muncul seiring meningkatnya jumlah pengunjung di dalam kawasan air terjun Tiu Teja.

\section{b. Agrowisata}

Agrowisata merupakan rangkaian kegiatan wisata yang memanfaatkan potensi pertanian sebagai obyek wisata, baik potensi berupa pemandangan alam, kawasan pertanian , kekhasan dan keanekaragaman aktivitas produksi dan teknologi pertanian, serta ilmu pengetahuannya. Kegiatan agrowisata bertujuan untuk memperluas wawasan pengetahuan, pengalaman, rekreasi, dan hubungan usaha di bidang pertanian yang meliputi tanaman pangan, hortikultura, dan perkebunan.

Secara umum konsep agrowisata mengandung pengertian suatu kegiatan perjalanan atau wisata yang dipadukan dengan aspek-aspek kegiatan pertanian. Pengertian ini mengacu pada unsur rekreatif yang memang sudah menjadi ciri kegiatan wisata, unsur pendidikan dalam kemasan paket wisatanya, serta unsur sosial ekonomi dalam pembangunan pertanian. Perpaduan antara kegiatan wisata yang dibarengi dengan kegiatan kegiatan yang bersifat edukatif di wilayah atraksi Air Terjun Tiu Teja dapat dilakukan dengan kegiatan seperti proses budidaya, pemanenan dan pengolahan tanaman perkebunan seperti kopi, durian dan beberapa jenis tanaman lain. Hal ini bertujuan agar wisatawan mengenal alam secara lebih dekat.

\section{c. Wisata IImiah/Edukasi}

Wisata ilmiah adalah pola perjalanan yang dapat memberikan nilai edukasi kepada wisatawan yang berkunjung pada suatu destinasi. Pola perjalanan seperti ini dapat ditemui di kawasan Air terjun Tiu Teja. Konsep pariwisata lain yang dapat ditawarkan adalah pengamatan flora dan fauna. Beberapa jenis flora yang terdapat di lokasi air terjun Tiu Teja yaitu Monyet ekor panjang, Lutung, kupu-kupu, beberapa 
jenis burung dan jenis satwa liar yang belum terdeteksi. Tutupan hutan di sekitar kawasan Tiu Teja juga memberikan peluang bagi wisatawan untuk dapat memperoleh edukasi terkait flora. Aktivitas ini dapat dilakukan sepanjang perjalanan menuju atraksi utama. Konsep ini dikenal dengan perjalanan wisata minat khusus atau special interest tourism.

\section{d. Wisata Budaya}

Lombok utara merupakan salah satu daerah yang tidak hanya terkenal dengan keindahan alamnya, tetapi juga dengan keunikan budayanya. Guna mendukung pengembangan Air terjun Tiu Teja sebagai salah satu destinasi wisata, maka wisata budaya yang dapat dikembangkan yaitu Gong Dua Santong Asli dan Klenang Asli Lombok Utara. Atraksi ini dapat memberikan nilai edukasi bagi wisatawan yang berkunjung ke Desa santong.

\section{e. Wisata Buatan}

Wisata buatan yang dapat menjadi atraksi dan menjadi ikon untuk Desa Santong adalah kerajinan bambu dan olahan makanan yang berasal dari buah-buahan asli desa Santong. Wisata buatan ini mendukung pemenuhan kebutuhan cinderamata bagi wisatawan yang berkunjung ke desa Santong.

\section{Kesimpulan}

Berdasarkan hasil penelitian yang telah dilaksanakan diperoleh kesimpulan sebagai berikut :

1. Karakteristik sosio-demografi dan grografis wisatwan menunjukan wisata Tiu Teja diminati oleh wisatawan mancanegara dengan jumlah $68 \%$ dan terdiri dari berbagai golongan usia dengan motivasi kunjungan terbesar adalah untuk berekreasi. Sejumlah $83 \%$ wisatawan menyatakan puas berwisata di kawasan air terjun dengan alasan yang mendasari kepuasan ini adalah landscape di sekitar kawasan Tiu Teja yang sejuk dan menarik, kondisi sungai yang jernih, dan pemandangan air terjun yang indah. Berdasarkan hasil wawancara juga diperoleh $17 \%$ wisatawan yang belum merasakan kepuasan di dalam berwisata, hal ini disebabkan karena beberapa faktor dominan seperti kesulitan pencapaian lokasi (43\%), sarana penunjang yang kurang memadai (27\%), kurangnya sarana akomodasi (13\%), kurangnya fasilitas perdagangan $(10 \%)$ dan faktor-faktor lain seperti keamanan dan keramahan dari masyarakat.

2. Masyarakat Desa Santong mendukung pengembangan Tiu Teja sebgai atraksi wisata dan melihat hal ini sebagai peluang untuk meningkatkan perekonomian masyarakat. Jenis atraksi wisata pendukung di sekitar kawasan wisata Air terjun yaitu air terjun seperti Skeper, Sampurarung dan Batu Lawang. Selain itu dapat dikembangkan Agrotourism, wisata budaya dan wisata kuliner.

\section{Dafar Pustaka}

Ichsan, A., Silamon, R., Anwar, H., \& Setiawan, B. (2016). Analisis Kondisi Sosial Ekonomi Masyarakat Di Sekitar Kawasan Hutan Dengan Tujuan Khusus (Khdtk) Senaru Dengan Menggunakan Pendekatan Partisipatif. Jurnal Hutan Tropis, 1(3). doi:http://dx.doi.org/10.20527/jht.v1i3.1541

Bungin B. 2003. Analisis Data Penelitian Kualitatif. Jakarta: Radja Grafindo Persada.

Desa Santong. 2014. Profil Desa Santong 2014. Lombok Utara (ID) 
Fandeli, Chafid 2001. Perencanaan Kepariwisataan Alam.Gadjah Mada Universiti Press. Yogyakarta

Fandeli, Cafid, and Muhammad Nurdin. 2005. Pengembangan Ekowisata berbasis Konservasi di Taman Nasional. Fakultas Kehutanan dan Pusat Studi pariwisata. Universitas Gadjah Mada. Yogyakarta

Kelompok Tani Maju Lestari. 2017. "Profil Kelompok Tani Hutan Kemasyarakat Maju Lestari. Lombok Utara (ID).

Kesatuan Pengelolaan Hutan Rinjani Barat, 2013. Dokumen Rencana Pengolaan Hutan Jagka Panjang KPHP Rinjani Barat 2014 - 2023. NTB Pemanfaatan Jasa Lingkungan Wisata Alam Pada Hutan Produksi

[KLHK] Peraturan Direktur Jenderal Pengelolaan Hutan Produksi Lestari Nomor : P.4/PHPL/SET/4/2017 tentang Pedoman penyusunan Desain Tapak Dan Desain Fisik, Pemberian Tanda Batas, Pembangunan Sarana Prasarana Pengusahaan Pemanfaatan Jasa Lingkungan Wisata Alam Dan Tempat Istirahat Pada Hutan Produksi.

[KLHK] Peraturan Menteri Lingkungan Hidup Dan Kehutanan Republik Indonesia Nomor P.31/Menlhk/Setjen/Kum.1/3/2016 Tentang Pedoman Kegiatan Usaha Pemanfaatan Jasa Lingkungan Wisata Alam Pada Hutan Produksi.

Mulyana D. 2006. Metode Penelitian Kualitatif. Bandung: PT Remaja Rosdakarya

R. G Soekadijo. 1996. Anatomi Pariwisata. Jakarta: PT Gramedia Pustaka Utama. 